\title{
Artelogie
}

artelogie Recherche sur les arts, le patrimoine et la littérature de l'Amérique latine

$10 \mid 2017$

Après le paysage : l'art, l'inscription et la représentation de la nature en Amérique latine aujourd'hui

\section{The Power of Interpretation (or How MoMA explained Guernica to its audience)}

\section{Andrea Giunta}

Traducteur : Jane Brodie

\section{OpenEdition}

Édition électronique

URL : http://journals.openedition.org/artelogie/953

DOI : 10.4000/artelogie.953

ISSN : 2115-6395

Éditeur

Association ESCAL

Référence électronique

Andrea Giunta, "The Power of Interpretation (or How MoMA explained Guernica to its audience) », Artelogie [En ligne], 10 | 2017, mis en ligne le 11 mai 2017, consulté le 19 avril 2019. URL : http:// journals.openedition.org/artelogie/953; DOI : 10.4000/artelogie.953

Ce document a été généré automatiquement le 19 avril 2019

Association ESCAL 


\section{The Power of Interpretation (or How MoMA explained Guernica to its audience)}

\section{Andrea Giunta}

Traduction : Jane Brodie

1 To represent a story in images does not mean to allay its topics on the surface of the canvas. On the contrary, the images themselves produce effects. Ideas that may not unleash major conflicts when communicated in written form incite unexpected responses when represented visually. Art images are not frozen in the time they were produced. We may stroll by still sculptures and serene paintings in a museum, beholding them as if they were vestiges of what has been, but their power remains, if in latent form. Their meanings can, at any instant, be reactivated in new presentations. The most seemingly harmless portrait might begin to quake before a gaze that sees in it an anomaly, a skewed meaning not anticipated by the artist.

2 Images, then, bear a certain danger, a latent threat-they might spin out of control. Recent history is rife with examples of violent reactions to images (the fury unleashed by crude representations of Muhammad in late 20051); censorship of images that had been exhibited for long periods and suddenly become "dangerous" (Attorney General John Ashcroft ordered that the exposed breast in the Spirit of Justice sculpture in the Great Hall of the Justice Department in Washington DC be covered ${ }^{2}$ ); and images, in certain situations, become inopportune (the tapestry representing Guernica in the hallway of the United Nations was covered when U.S. Secretary of State Colin Powell announced the end of negotiations with Bagdad, which was sure to lead to merciless bombing of that city ${ }^{3}$.

3 To interpret images, though, does, in a way, mean to allay them. Analyzing them to delve into new layers of meaning makes it possible to control unforeseen reactions. The more arguments deployed to show that the correct interpretation of the image has been reached-the most well documented and solidly grounded-the less the chance that that image will grow unruly. Anyone who strives to reach the true interpretation of a work 
subscribes to the idea that it has a sole interpretation. Any other that claims to be true is written off as fantasy, falsehood, lie.

These considerations are an apt way to introduce a specific moment in the interpretation of Picasso's Guernica. In 1947, Alfred Barr-director of MOMA from the time of its founding until 1943 and then, starting in 1947, head of its collections-organized a symposium to reach agreement once and for all on the painting's meaning. The debates that arose at that symposium demonstrate that, for Barr, the problem of Guernica's meaning-and solving it-had become paramount. Until 1947, he had been convinced that his interpretation was correct; it was based on reliable sources like the words of the artist, as well as his most characteristic iconography, and the very history of Western art. But, that year, Spanish poet Juan Larrea published, in English, the book Guernica. Pablo Picasso, ${ }^{4}$ in which he posited a conflicting interpretation. Barr was not slow to react. Larrea could not easily be ignored: he had been key to the painting's commission. The new interpretation baffled and disconcerted Barr. For him-and, as we shall see, for Larrea as well-it was not a question of exchanging ideas in order to assess the merits and faults of each possible interpretation, One had to prevail over the other.

In the ten years between the time Picasso painted Guernica and Barr organized the symposium, the Spanish Civil War and World War II had transpired and the Cold War had begun. The painting was an active player in all of those events. The comings and goings of the work, and of the artist who created it, were increasingly important. During those years, analyzing what the painting meant was no less important than determining what the artist thought-about the painting and everything else-and what he did. Both were topics of debate that needed to be resolved.

6 Why was it so pressing for Alfred Barr to establish the painting's ultimate meaning? My hypothesis is that it was mostly to pacify it. The work was a crucial item in the Cold War's symbolic clashes; if Barr was able to keep at bay the work's potentially explosive consequences, he could turn it into an ace up his sleeve, something to be deployed with surgical precision at just the right time. Establishing the painting's meaning implied diminishing its political visuality. Once properly placed in modern art history, every last detail of its possible meanings scrutinized, the painting would be sheltered from harsh political disputes and free to shine, in all its spellbinding radiance, in the best display case modern art had to offer, mainly the museum whose collection Alfred Barr had shaped.

7 In November 1939, Guernica arrived at the Museum of Modern Art, New York where it was on loan until 1981. The painting's arrival coincided with the outbreak of the war-a war whose horror the image foretold. In its brief history, the painting had taken on meanings that exceeded its aesthetic value or renown, or even the talent of its author. New York and its museum had become the custodians of a work that held the very freedom endangered by the advance of Nazism. The painting was much more than a good work by a good artist. In the context of the alignments forged by the beginning of the war, this image, in many and varied ways, was a force on the battlefront.

8 Alfred Barr planned to present Guernica at a retrospective that, for years, he had longed to organize. Picasso, Forty Years of his Art represented a particular challenge. Barr not only wanted to exhibit the artist he considered the maximum representative of twentiethcentury art, but also to outdo all other museums by organizing the best and most exhaustive exhibition of his work ever held. ${ }^{5} \mathrm{He}$ empathically did not want to relive his first and frustrated attempt to hold a show of Picasso's work, in 1931-1932, a saga that it had taken him over a year to recover from. ${ }^{6}$ In one sense, the current circumstances were 
worse than in 1931, since the world conflict complicated communication and the shipment of works. Overcoming all of those obstacles was, for Barr, a personal challenge, one that, in the context of the war, took on new dimensions. ${ }^{7}$ Indeed, the telegrams he sent to Picasso informing him of the exhibition's success were like reports from the front telling of battles won:

Exposition succes colossal soixante mille visiteurs surpassant exposition Van Gogh STOP. puisque guerre em(p)eche renvoi vous tableaux espere votre contentement leur inclusion tour triomphal grands centres culturaux etats unis. STOP. ${ }^{8}$

With this exhibition, Guernica became part of art history. It would be viewed as the culmination of the narrative of modern art, the crowning work of the artist who had transformed twentieth-century art and who, at the end of the conflict, would enjoy a hero's status.

Picasso's whereabouts and behavior were topics of public debate during the war years. ${ }^{9}$ In the conflict's first months, the world's newspapers wondered about his whereabouts (it turned out he was in Royan, where he would stay for almost a year, from September 1939 to August 1940). It was even speculated that after the occupation of Paris, in 1940, the Nazis had sent him to a concentration camp. By early 1942, it was known that Picasso had returned to Paris, where he was leading a normal life, painting and sharing meals with friends, though he did not receive any special favors from the Nazis. At the beginning of what would prove to be a particularly cold winter, he left his studio on Grands-Augustines Street; all he had there was a woodstove-and wood was in very short supply. He started working at his home, where he had electric heating. Vogue magazine published a story that proved that Picasso was not negotiating with the Nazis. One night, after offering Picasso wood, butter, sugar, chocolate, and cigarettes-all of which the artist had refused -Otto Abetz, the German Ambassador who had organized the fifth column in France, asked him how he had painted Guernica. Picasso's reply was blunt, "No, you did it." The story only served to heighten his glory. Not much was known about him until the end of the war, when it was learned that the great artist had painted despite all the hardships the war had brought. ${ }^{10}$

Once the war was over, reports on Picasso's whereabouts were once again in the news. The day Paris was liberated, Picasso appeared in photographs next to Ally soldiers; they had found him in his studio where, despite shortages of all sorts, he had worked intensively throughout the war. The photo of Picasso in fur coat, belt around his waist, with his Afghan hound Kasbek, next to a woodstove that could not be lit during the war years sealed the artist's hero status. ${ }^{11}$ Picasso's public conduct during the war provided a concise response to the question of what had happened to Western culture and Parisian art during the Nazi occupation. The physical and moral salvation of the artist proved that the West and its culture had made it through safe and sound..$^{12}$

As soon as Paris was liberated, Alfred Barr tried to get in touch with Picasso. On September 25, 1944 he sent a card to his studio on Grands-Augustines Street: "Now that the end is ours we can send you a postcard. We know that you worked very hard during the War and we hope to see the paintings you have done since 1939 in the not too distant future." ${ }^{13}$ Though brief, the message conveyed the urgent desire for news not only of the artist, but mostly of his work. ${ }^{14}$

13 The story of Guernica might have been perfect if Picasso had limited his political positions to the surface of the canvas. But, in October 1944, he officially joined the French Communist Party. In an interview with Pol Gaillard published in New Masses and in 
L'Humanité, Picasso stated that, using the weapon of his art, he had always fought like a true revolutionary. But, he went on, after the experience of World War II he understood that expressing political sympathies under the guise of artistic expression was not enough..$^{15}$ Picasso explained that he was joining the Communist Party because its members had fought harder than anyone else, their thinking was clearer than anyone else's, and they themselves were the freest and happiest of all. In their midst, Picasso felt he was with "brothers"; they were now his "family."16

One day after that news got out, his exhibition at the Autumn Salon began; the opening ended in scandal. ${ }^{17}$ The audience found the skulls, the violent portraits of Dora Maar, and the sculptures with handlebars and bicycle seat incomprehensible and unpleasant. They didn't even tell the story of the war. Picasso had told Peter Whitney: "I didn't paint the War because I'm not the kind of painter who goes after something to paint like a photographer. But I have no doubts about the fact that the War is in these paintings I made." ${ }^{18}$ Viewers tore the sculptures to pieces and burned reproductions of them. After those incidents, the show was under the care of guards. Les Lettres françaises, the French Communist Party's newspaper, considered the assaults on the works "acts of the enemy" and "vestiges of the intimidation tactics experienced during the Nazi occupation." ${ }^{19}$ The newspaper took it upon itself to represent liberated France and to defend the artist-but not necessarily his work: the cover of Les Lettres showed an image of a work by Fougeron, not one by Picasso.

Alfred Barr was aware of all these events, that is, of Picasso joining the Communist Party and of the scandals at the Autumn Salon. ${ }^{20}$ From then on, he followed closely the artist's relationship to the Party. ${ }^{21}$ The delicate problem Barr now faced was how to separate the public man from his work, especially from Guernica. The solution did not lie in mincing words-in the text Barr wrote for the exhibition Picasso. Fifty Years of His Art he organized at MOMA in 1945, the word "communism" appeared twice and "Communist Party" three times-but rather in relativizing their weight. The arguments are common knowledge: the figure of Picasso had grown in importance during the Nazi occupation and continued to grow after he joined the Communist Party, but none of that was expressed explicitly in his art. As Picasso had explained to Whitney, not even the paintings he had made during the war could be seen as a description. There is a great deal of information to suggest that neither the Nazis nor the Communists officially approved of his painting. But that did not lead the artist to change his language during the occupation or after joining the Party; Picasso was not one to subscribe to political theories about art. He and he alone was responsible for what he did-and he made the work he made due to his own motivations.

In his text for Fifty Years of His Art, Barr drew strategic differences: he separated the artist from the man and Guernica from the rest of his work, from propaganda, and from the specific context in which it had been painted; he distinguished Picasso's political position from the position of the Communist Party and turned him instead into a representative of the Allies and their policies. Barr was able, thanks to all of those operations, to change the artist's problematic political affiliation into something less troubling. By differentiating aesthetic positions, Barr could brush over the division of the world into two blocks that was taking place at that very moment. When, in 1952, The New York Times published his article "Is Modern Art Communistic?" he brought to a close the operation of separating modern art, insofar as Western cultural patrimony, from both Communists and reactionaries, placing it in the terrain of liberals, the representatives of democracy and of freedom. ${ }^{22}$ 
Barr thus managed to work around all the trouble caused by Picasso's political leanings. But soon something else came along that upset the delicate construction he had used, until that point, to work his way around the contradictions surrounding the artist and his work. The problem had to do with something crucial to Barr, something resistant to classification, mainly, the meaning of painting.

B In 1947, the book that Juan Larrea wrote on Guernica was published in New York. Argumentative and complex, the work collided head-on with existing iconographic analyses of the painting. ${ }^{23}$ On the basis, mostly, of what Picasso appeared to have said in an interview with American soldier Jerome Seckler-an interview the artist had approved -there had been, up to that point, a certain consensus on what each of the figures in the painting represented. In addition to the tone of Larrea's book, what surprised Barr was the author's reversal of the painting's iconographic meanings; all the meanings Barr felt sure of were thrown into question. According to Seckler, Picasso said that the bull represented barbarism and, therefore, Franquismo, and the horse the people, that is, the Republican people. Larrea argued just the opposite: the bull was the people and the horse the Fascist enemy. Victims and victimizers had changed places.

This reversal of meaning was important to Larrea. Arguing that the bull-brimming with life and defiant in the painting-represented the triumph of the worthy Spanish people meant that the painting bore a message of hope. The Franquistas may have won many battles, but they had lost the future. For Barr, the change in roles as such was not a problem; the painting was still about war and violence-its general meaning unchanged. The real problem was the fact that the interpretation could be altered so readily, regardless of what Picasso himself may have said.

By 1947, Barr cared less about separating the work from the artist's political leanings and about determining to what extent it was art and to what extent propaganda. What mattered now was controlling its meanings; if it could be argued that the same characters represent such different things, then it was possible to assert anything at all. Barr could not leave a work so crucial to the museum and so vulnerable to the strange atmosphere of the postwar period to such a vague and uncertain interpretative fate, where anyone could make the painting say whatever served their interests.

There were a number of different incidents in the battle over the meaning of Guernica in these years. The conflict began with the publication of Larrea's book and the intense correspondence between Barr and Larrea-separately of course-and those close to the artists and experts in his work (figures like Daniel-Henry Kahnweiler, Michel Leiris, and José Luis Sert); it continued with the symposium Barr organized at MOMA in order to bring all the conflicting views together in one venue; and it ended with the explanation of the painting's meaning that MOMA hunged next to the painting.

22 As soon as he had read Larrea's book, Barr wrote to Kahnweiler-Picasso's dealer, to whom he had easy access-asking him to help get a definitive statement from Picasso on the question at hand.

As you perhaps know there is a very real confusion about the symbolism of the Guernica. Picasso himself seems to have increased the confusion by apparently confirming contradictory interpretations of the symbolism of the bull and the horse.

(...)

The question is simply: does the bull represent the triumphant Spanish people or does it represent brutality (more specifically the nationalism of the Franco 
government)?

Does the horse represent the suffering and martyred Spanish people or does it represent the wished-fro collapse of the contemptible Fascist Government? ${ }^{24}$

In case Picasso's answer proved ambiguous, Barr provided Kahnweiler with two clear options, the first from Seckler's interview and the second from Larrea's book. One week later, Kahnweiler's answer arrived. He described his encounter with the artist:

Today I saw Picasso, and read your letter to him. What he answered is this. I give you own words in French:

Mais, ce taureau est un taureau, ce cheval est un cheval. Il y a aussi une sorte d'oiseau, un poulet ou un pigeon, je ne me souviens plus, sur le table. Ce poulet est un poulet. Bien sûre, les symboles... Mais il ne faut pas que le peintre les crée, ces symboles, sans cela il voudrait mieux écrire carrément ce que l'on veut dire, au lieu de le pendre. Il faut que le public, les spectateurs, voient dans le cheval, dans le taureau, des symboles qu'ils interprètent comme ils l'entendent. Il y a des animaux: ce sont des animaux, des animaux massacrés. C'est tout, pour moi. Au public de voir ce qu'il veut voir.

But this bull is a bull and this horse is a horse". There is also a kind of bird, a chicken or a pigeon, I don't remember now, on the table. This chicken is a chicken. of course, the symbols... But it isn't necessary for the painter to create these symbols, otherwise it would be better to directly write what we want to say, instead of painting it [...] There are animals: they are animals, massacred animals. To me, that is all. It's up to the public to see what they wish. ${ }^{25}$

Kahnweiler wrote Picasso's response down the same day the two men met, and added his own opinion:

That is exactly what he said. And he thinks what he says. Besides, if you ask my opinion, it seems to me that Larrea is wrong. Picasso says: des animaux massacres. Well, the bull is not "un animal massacrée". There are "des humains massacrés", and "des animaux massacrés". There is the bull, alone, who is not. It is the bull who is brutality, who is Franco. That is not conscious, with Picasso, but it is clear for me. The others are the sufferers... horse, humans, etc....." ${ }^{26}$

Kahnweiler kept thinking it over, and the next day he wrote Barr again:

I talked yesterday evening, with my brother-in-law Michel Leiris about the Guernica-question, and he, who is "aficionado", who loves bull-fights, as Picasso does, said that it was quite impossible that for an aficionado the bull could mean Franco, oppression, etc." The bull, too, always dies -es massacré"- he said. He is right, I believed, and when Picasso talks about animaux massacres, the bull, too is one of them.

So, the symbol of Guernica is not twofolded. There is not Franco and the Republic, there are only killed humans and killed animals. The sense of it is -pity, pity only with the suffering world. The same pity Picasso felt for the blind, crippled, prostitutes of the blue period. I had felt it, and said it in my book about Gris. What Picasso said yesterday, proves it. ${ }^{27}$

With that information, Barr wrote to Larrea about the differences between his interpretation and the interpretations of English and North American critics. He explained that for the last three years he had tried to come up with a convincing account of the meaning of the painting's iconography, mostly on the basis of what Picasso had said to Seckler, but now he found that Larrea's book was turning his conclusions on their head. He then copied Picasso's response to Kahnweiler and what Kahnweiler had said about the meaning of the bull; he didn't mention Leiris's opinions. Barr then asked Larrea:

Won't you let me know what definite evidence you have that your interpretation of the bull and the horse is correct. Have you ever had any conversations with Picasso 
or is your opinion based upon general deductions?

I hope my questions will not inconvenience you. We must all agree that the interpretation of this great painting is one of the most important critical problems before us. ${ }^{28}$

The response Larrea wrote on July 1, 1947 probably confounded Barr still more since it provided an explanation based on cultural differences. Larrea affirmed that what Picasso had said to Seckler and to Kahnweiler was ambiguous, and that that ambiguity had been poorly handled by the interviewers. Picasso had once said to Christian Zervos, "I should like to arrive at a point so that one could never tell hay the painting was made" 29 which is why he let Seckler reach such mistaken conclusions. He had even let him say that the bull, the only figure with eyes wide open, represented darkness, while the horse, whose eyes were atrophied, stood for the Spanish Republican people. Larrea's argument was based on knowledge of Spanish culture: "I tell you the opposite so that you understand me is frequently used Spanish proverb when one is playing with antonyms"30 --Larrea pointed out. And he went on, "It is advisable to point our, to be exact, that the horse represents the people: the Falangists, of course". ${ }^{31}$ This interpretation led to the belief that Picasso had manipulated Seckler and let him write something clearly erroneous, almost as if he had wanted to mock him to show that to understand a Spaniard you have to know his codes, the ins and outs of his way of speaking and of making arguments. With that reasoning, Larrea shot back at Barr his own observations: if English and North American critics understood things differently, they misunderstood them.

Given this state of affairs, Barr decided that the best way to settle the question would be to organize a symposium-a battle in which the two sides would devise strategies on the basis of letters and statements. Just as Barr had gotten in touch with Kahnweiler to ask him to reach out to Picasso, Larrea had asked José Luis Sert to deliver his missive to the painter. Dated September 6, 1947 and written in Mexico City, Larrea formulated the problem in warlike terms:

...the militiaman Larrea has something to ask of militiaman Picasso. [...] Without having proposed as such, as circumstance would wisely have it, one of the most important units of weaponry that I have at hand today is Guernica. I believe you already know why. I am sure that you are also aware that the critics who we might call international have made efforts to domesticate the painting and they are sure that they have already made it serve to suit their convenience, stripping it of the subversive imaginative force it contains. Not only have they already saddled up the horse, but want to take the bull with them as a stud for their-very haltered-cattle breeding. The simple fact is that this critique clings to and as long as no one prevents it will continue to cling to several misinterpreted confidential points of yours that, according to what they say discard any possible discussion, since you yourself have uttered the last word by approving the text of the interview from which these points were extracted. Don't they maintain that, after J. Seckler's declaration that the figures in Guernica are of an allegorical nature, you declared that the old nag represented the Spanish people? They haven't understood anything. As if this weren't enough, what is happening now is that Kahnweiler, following a conversation with you to the same ends not too long ago, now believes he has the right to proclaim that the bull in Guernica represents Franco and his movement. He's understood even less. Plus the whole thing begins to be alarming because of the authority that Kahnweiler enjoys among lovers of painting. So as it turns out, if on the one hand they are practically calling you pro-Franco without realizing it, on the other, by depriving Guernica of its second psychic intention, they are taking away from Spain's republican people the pictorial credential that demonstrates how effectively they were assisted by reasons of a higher order 
during the war days. In summary, they are playing into the enemy's hands without realizing it.

This is why I am on the eve of battle-it's high time-and I need you to help me. Referring to J. Seckler and whatever reach his approval of the text of the aforementioned interview [...]. "Give me that scrap of truth now, when it will burn, and you'll see what will be readied in the center of universal resonance that is the United States today. I bet that it will be something they'll never forget."-he wrote to the artist. ${ }^{32}$ that Picasso could sign the one he found most accurate. His signature would, in a sense, act as a "certificate of the right interpretation":

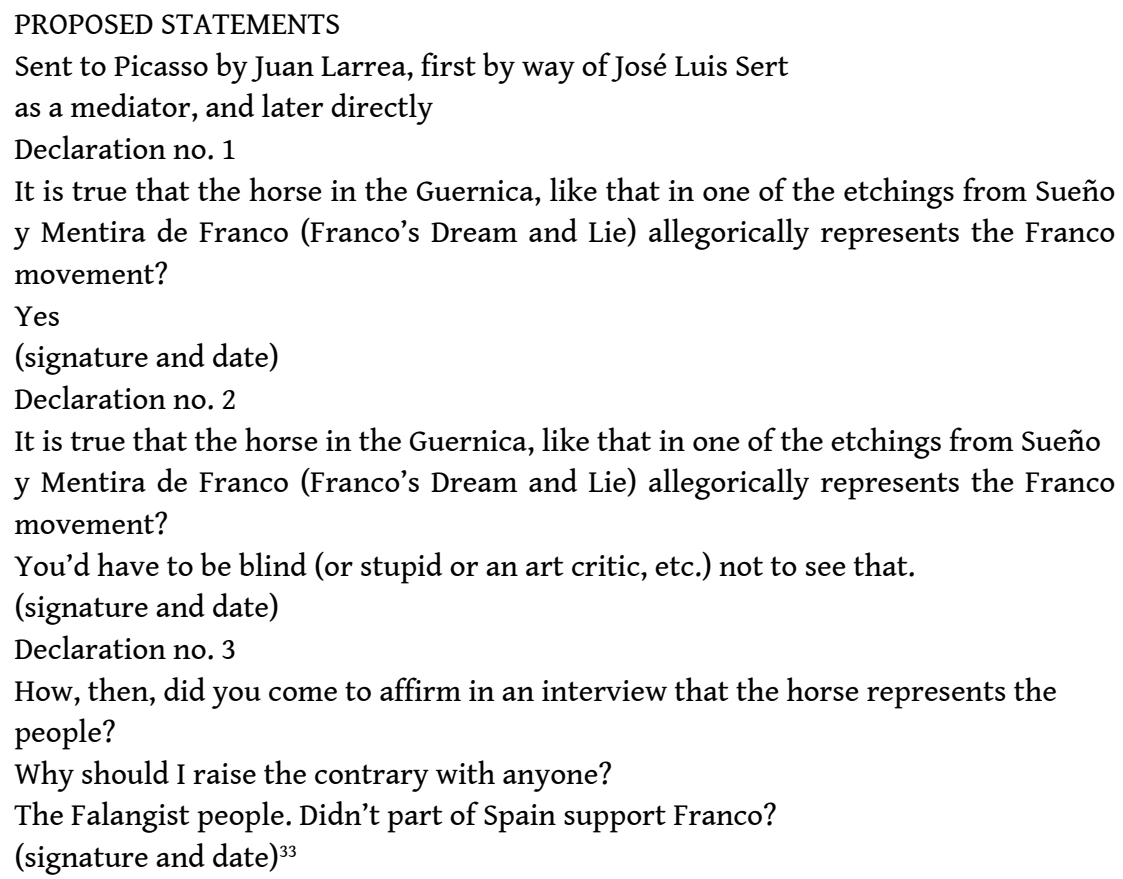

Needless to say, Picasso never signed any of those statements.

During the weeks that followed, Barr and Larrea each planned his own strategy for the symposium. Barr tried to keep Larrea from going over the time he was allocated, and Larrea to come up with a good translation of his text. Leaving no detail unattended, Barr wrote to Monroe Wheeler, the director of MOMA, about the problems that Larrea's arguments might bring:

Larrea's interpretation is so extremely complex and arbitrary iconographically, and depends so much upon a knowledge of Spanish soul (?) as well as interpretation of Picasso's private symbolism (is the horse his wife?) that it is hard to see how you could spread this thesis in an evening occupied by other speakers plus an interpreter. ${ }^{34}$ Larrea, meanwhile, requested that Sert not be the one to read his paper, mostly because he suspected that he might introduce his own interpretations, which differed from Larrea's.

The Symposium on "Guernica" began on November 25 at 8:15PM. The participants were José L. Sert, Jerome Seckler, Juan Larrea, Jacques Lipchitz, Ben Shahn, and Alfred H. Barr, Jr. In two and a half hours, the presentations formulated different positions; some of them were fairly ironic in tone. 
Addressing the audience, Barr explained the controversies that had surrounded the work from the outset. Some considered it a "romantically Victorian mural" that had none of the heroism of Guernica (Francis Henry Taylor in Babel's Tower): "Mr. Taylor speaks, I think it is fair to say, from a conservative point of view. Yet, he has strong support from the orthodox Left," ${ }^{35}$ stated Barr. Others, like Herbert Read in the London Bulletin, considered Guernica a religious painting, every bit as fervent as Grünewald's works. A great work steeped in passion, it went beyond all categories of school and tendency.

After Barr's introductory remarks, Sert began his testimonial presentation, which made reference to first-hand experiences during the making of the work, explaining that he would not address the meaning of the painting-his friend Larrea would do that, and much better than he ever could. His talk revolved around how difficult it had been for Picasso to come up with the theme of the work and for viewers to understand it. Then Barr was given the floor once again, and he began making his case, which was the crux of the symposium. There were two contradictory interpretations of the painting, he explained, Seckler's and Larrea's. Each would exhibit his point of view.

Seckler made his presentation first. He explained that he had not initially intended to accept the invitation to participate in the symposium, but that when Lipchitz conveyed to him Larrea's opinions-which wholly contradicted his own-he was shocked: Guernica had been turned into a sort of cosmic cryptogram and Picasso a religious mystic. He felt he had no choice but to participate. ${ }^{36}$ Reflecting on his interview with Picasso, Seckler now believed that he had made the same mistake as Larrea. Picasso had not said that the bull represented Fascism, and when he said that the horse represented the people, he did not specify whether it was Republican or Fascist. When Seckler read the first interview to Picasso, translating it from English to French along the way, Picasso thought that he was writing down the words Seckler had uttered, saying that the bull represented Fascism. And the artist explained that that was not the case, that the bull did not represent Fascism. Seckler explained to Picasso that he had not said that the bull represented Fascism, but darkness, brutality and that, for the whole world, Fascism was brutality, death, destruction.

Yes, you are right -Picasso answered--, but I did not try consciously to show that in my painting. If you interpret it that way, then you are correct but still it wasn't my idea to present it that way $20-21 .^{37}$

For Seckler, Larrea's interpretation, which saw the horse as the Franquista beast and the bull as the Spanish people, rested on reducing the painting to a mistaken pictographic formula, a misuse of psychoanalytic method. What Larrea had to offer were his own associations. The last part of his book was the part that Seckler had found most troubling, especially when he spoke of "cosmic ghosts" with "funcy names" carefully written in upper-case letters ("the Spirit of History," "Creative Intelligence," "Logos," "Essence" and "the World"). ${ }^{38}$ These entities were the foundation for his idea of the Psyque, a collective soul that Larrea mistakenly attributed to Freud on the basis of an interpretation in no way scientific. Larrea-Seckler went on-asserted in his book's crowning argument that Picasso painted the death of the European world and the transfer of culture, science, and everything bound to humanity's progress to the New World, that is, to America. "On what does Mr. Larrea base himself?", asked Seckler, before making sarcastic reference to some of his "evidence." ${ }^{39}$ First, the fact that Michelangelo painted The Last Judgment after the discovery of America. Second, that in Géricault's celebrated The Raft of the Medusa, the sole survivor stares into the horizon, looking for the rescue boat; given that the painting was 
made in the year of Spanish America's independence, the survivors symbolize Europeans seeking salvation, and where do they look for it? And where exactly did they look for it? "To the West (...) America! exclaimed Seckler, while the audience burst out laughing. ${ }^{40}$ For Larrea, "the bull, mother, the child, and the bird are the "occidental" part of the canvas. ${ }^{41}$ "And where does this all point to? To the West, of course, America? ${ }^{42}$ Parodying Larrea's arguments, Seckler conjectured about their consequences, describing Picasso at the moment the idea of the painting came to him: "I can just see Picasso now, sitting with his head in his hands, saying, Pauvre Europe? Pauvre Europe?" ${ }^{43}$ Because of the scene he described, the images he conjured, and the quotes from Larrea that he chose, Seckler's hilarious response mocked Larrea's arguments. "We are not here tonight to discuss Mr. Larrea's dreams or the New World view which he reads into the Guernica. What is important is to show that this hypothesis is not Picasso's." ${ }^{44}$ he concluded. He was not satisfied with ridiculing Larrea's interpretations; he wanted to shatter them. "Thank you, Mr. Seckler!" said Barr, with palpable admiration. ${ }^{45}$

It seemed, at this point, that Seckler had defeated his rival. Larrea's presentation started out muddled and disorganized. He began with some words in French that no one took the trouble to translate ${ }^{46}$ and then Wheeler started reading his presentation in English.

Larrea described the meeting as a "tribunal" gathered to examine the fundamental question: the future of art. The encounter formulated a basic issue in the study of art, mainly, on what grounds should a work be interpreted, what are the limits of interpretation, and whether in interpretation the artist's word outweighs the critic's. In the interview with Seckler, Picasso made it perfectly clear that, when he was making the painting, he was not thinking what Seckler thought he was, but that Seckler, and viewers in general, were free to come up with their own interpretations. If what Picasso said to Seckler is compared to what he said to Kahnweiler, it would seem that Picasso was not always telling the truth. And that meant that people were entirely free to draw their own conclusions, even if they contradicted what the artist himself had said.

To settle the confusion created by the Seckler interview, Larrea was going to present a series of elements that would show a logical progression in the artist's thinking. To say that the tortured Spanish people were represented by the horse and the diabolic forces by the bull amounted to saying that Picasso was not trying to work through any creative problem at all, but just describe two clashing forces. The differences between the interpretations were culturally based. For Anglo-Americans, the horse was the noblest of beasts, whereas the bull was dark and aggressive. But the work had not been painted for the Anglo-American audience, but rather for the Spanish people; that is why it made use of Spanish symbols that would incite emotions in the Latin sensibility. For the Spanish, the bull was a sacred animal, a mysterious totem of virile power, a beast admired for its courage in the face of death. The horse, on the other hand, was a decrepit and ridiculous animal in bullfights, a repulsive walking skeleton. Picasso would never have used it to portray the Republic "Therefore, I am not afraid to affirm that when Picasso said -or let Mr. Seckler say-that the horse represents the people, he meant the Spanish Falangist people. As a matter of fact, the Falangist are also people." ${ }^{47}$ At this point, the audience started laughing.

41 Larrea showed Picasso's sketches to argue that it was clear that Picasso made a distinction between two types of horses: the noble, winged horse associated with the bull as poetic symbol, and its opposite, the moribund and vile horse of the bullfights. In The Dream and Lie of Franco, Franco killed Pegasus with an arrow, the symbol of Falangist 
Spain. The second horse, the one with its stomach open, was the one that represented Franco. Larrea considered the bull a masculine animal and the horse a feminine one-and, for the Spanish, the female, woman, lacked courage. Larrea now turned his attention to the horse pierced by a spear, drawing a parallel with pre-historic images where that image was believed, by magic, to provide good luck in a hunt. "But who has pierced him?" Larrea asked. "The soldier (...) the bull?," Larrea asks himself. ${ }^{48}$ No, it was Picasso himself, "in a magic action against Franquismo." ${ }^{49}$ One of the most moving sections of the painting is the one that holds the mother, the child, and the bull. In the painting, the bull, its virility accentuated by sexual symbols, seems to possess the woman. Symbol of the power and virility of the Spanish, the bull protected the mother against Franco's evil. At the same time, that entire group was also a hieroglyphic for Spain (in the middle was the capital city, Madrid, "mother"). The other caracther represented in the painting was the woman under the lampshade who, present in even the earliest sketches, represented the Republic. She was an effective weapon against Franco's obscurantism, that is, against the horse.

Larrea saw Guernica as a perfectly planned work. On the one hand, it performed the necessary task of working magic against Franquismo, contributing to the defense of Madrid and the hoped-for triumph of the Republicans. On the other, it needed to conceal that aim in order to incite a more intense emotion in each viewer. For Larrea, that explained why, in his statements to an Anglo-American, Picasso was forced to resort to a double entendre: he wanted to protect his painting's mystery. When he said that the dove was a chicken, he was saying the first thing that came to his mind-to keep from being found out. The meaning of the painting was apocalyptic. It announced the end of our era, and it was destined to further and to illuminate the transition to the new world, the transfer of the creative spirit from Europe to America. And that was how Larrea closed his presentation, to the applause of the audience. ${ }^{50}$

Without thanking Larrea or Wheeler, Barr quickly gave the floor to Lipchitz, who defended the role of criticism in interpretation and, specifically, Larrea's interpretation, by telling an anecdote. Larrea had once visited him in his studio in Paris while he was working on a sculpture. He remarked on something that had never occurred to the artist during the six months he had been working on the sculpture-something that, to Lipchitz's surprise, was right on the mark and that "Only the sharp eyes of Larrea showed it to me" 51 . The critic, then, was able to see more than the artist and, with that observation, Lipchitz sided with Larrea. For him, Guernica was, first and foremost, a painting, not even the artist's best: the preliminary sketches were average, the use of the allegorical figures not particularly brilliant, and the limited palette rather unexciting, in his view. He found trying to figuring out what the bull and the horse meant less interesting than working out a crossword puzzle (the audience once again laughed). For Lipchitz, the theme of the work was one of the artist's concerns, and art was not catharsis or an act of purging or purification. It was the active use of the same faculties that allow us to understand everyday life, that is, the application of a specific method, of a sense of balance and of space in the artist's work. Interpretation, Lipchitz seemed to argue, was more a concern of the critic than of the artist, whose sole mission was the creation of the work.

And then it was time for questions. From the audience, Walter Pach stated that Picasso often refused to answer questions, which he felt might corrupt the work and invade his privacy. He recalled that, despite the evident connection between Picasso's work and 
African sculpture and the fact that his studio was full of it, when the artist was asked he said, "African sculpture? Negro sculpture? I have never heard of it!" ${ }^{2}$ The audience laughed and applauded.

Pach's comment showed that the scene Barr had put together to de-authorize Larrea had fallen apart. After two and a half hours of discussion, his principle witness had been discredited. The idea that the meaning of the painting did not lie in Seckler's oft-cited interview was what ended up getting the most applause. After Seckler's ironic and dismissive introduction, Sert and Lipchitz had ended up siding with Larrea. Even though Larrea had, over the course of his presentation, seemed quite unhinged at times, speaking French with no one to translate for him, everyone-even Seckler-ended up defending his right to interpret the painting as he saw fit.

The encounter ended in the conclusion that to decode the painting's meaning would undermine its artisticness. Barr understood that stating outright what each figure represented meant taking the work into a perilous realm where art ceased to be art to become illustration, or even propaganda, making way for a moralizing reading with ends akin to those of social realism. Larrea argued that the painting demonstrated the United States' duty to continue to support the heroic struggle of the Republic and its ideals. The war that had been lost in Spain would be won in America. Clearly, condemning the barbarism of the Nazis did not, in and of itself, mean becoming an instrument of the Spanish Republic. It's hard to imagine that Barr was interested in having that sort of ticking time bomb on the wall of his museum. His task was to use the means at his disposal to try to deactivate it. If Barr wanted Guernica to be considered art-indeed, the best art the twentieth century had produced-he had to make its meaning as general as possible. He could not deny its connection to a specific event, but that did not mean finding a meaning for each of its figures, enabling those meanings to be deployed beyond the confines of the work and of the specific time when the historical event in question ensued-that is, April 26, 1937, the day the bombs were dropped on Guernica.

According to the documentation in the MoMA Archive, the caption explaining the painting was hung by its side from as early as 1955 (the year that appears on the revision of the draft of the text) until 1980. In three paragraphs, the text provides just enough information to understand the political events that inspired Picasso to make the painting and its meaning. The text contradicts the denial of the bombing of Guernica by Franco's Spain, explaining that Guernica, the former capital of the Basque Country in northern Spain, had been "largely destroyed." Second, it blames the German for the bombing, even though it was not until 1997 that Germany recognized responsibility and formally apologized to the one hundred and fifty survivors of the bombing. ${ }^{53}$ Third, the text explains that Guernica was the first case of "saturation bombing" of a city in military history. Finally, the text explains that the bombing was what led Picasso to choose that theme for the mural he had been commissioned to make for the Pavilion of the Spanish Republic at the 1937 Paris Exhibition. When it comes to the interpretation of the work, however, the label is as general as possible. "There have been many and often contradictory interpretations of the Guernica. Picasso himself has denied it any political significance, stating simply that the mural expresses his abhorrence of war and brutality."

With those words, the museum did away with any trace of the debate on the work's iconography that had so obsessed Barr. Focusing the analysis on the characters, as if it were a battle between the good guys and the bad guys, meant arguing that the painting 
was strongly grounded in realism, that it was tied to history in a specific and concrete manner, and that it could be interpreted pedagogically. To uphold that-which was, after all, what had initially driven Barr to organize the symposium-meant getting caught up in the traps of realism. The caption in which MoMA explained the painting to its audience was a privileged platform from which to deactivate that reading.

In the context of the early Cold War, when the world was being divided into two blocks, battles over the meaning of culture and of art mattered a great deal. If the Communist Block had been able to claim the artist as man, Alfred Barr, would claim his work for the Free World. To write the meaning of the painting, to sum it up in a text that, for almost thirty years, would hang next to the work, was to win a battle that, though symbolic, was no less crucial than those fought with other weapons.

\section{NOTES DE FIN}

1. See Jyllands-Posten Muhammad cartoons controvery," Wikipedia. Accessed February 2, 2017. https://en.wikipedia.org/wiki/Jyllands-Posten_Muhammad_cartoons_controversy

2. "Curtains for semi-nude justice Statue”, BBC News, January 29, 2002. Accessed January 3, 2017. http://news.bbc.co.uk/2/hi/1788845.stm

3. Michael R. Orwicz y Robin Adèle Greeley, "El Guernica, Abu Ghraib y el espectáculo de la guerra," in Andrea Giunta (Ed.), El Guernica de Picasso: El poder de la representación. Europa, Estados Unidos y América Latina, Buenos Aires, Biblos, 2009, pp. 129-160.

4. Juan Larrea, Guernica. Pablo Picasso, New York, Curt Valentin, 1947 (edición castellana: Madrid, Cuadernos para el Diálogo, 1977).

5. The exhibition brought together 362 works from different periods and the catalogue-a joint publication of MOMA and the Chicago Art Institute-reproduced 217 of them. According to Oliver Larkin, the catalogue encompassed absolutely everything: bibliography, list of the ballets for which the artist had designed sets and wardrobe, chronology, chart of the different places he had lived, list of books he had illustrated, titles of his paintings in museums and collections in the United States, two texts in which the artist advocated revolution against commonsense, and a set of insightful remarks by Barr, pointing out-like a skillful guide-strategic moments that would help the reader understand the continuities in the work of the world's most talented artist. See Oliver Larkin, "One-Man Show", Saturday Review of Literature, New York, December 16, 1939. The show was on exhibit at MOMA from November 15, 1939 to January 7, 1940, and at the Chicago Art Institute from February 1 to March 3, 1940. Eighteen museums and forty-four private collections in the United States loaned works for the show; others came from the artist's own collection. It was the largest Picasso retrospective to have been held anywhere.

6. Picasso was, for Barr, a passion and a headache. In 1932, after a year of negotiations with the artist and his dealers, the exhibition planned for MOMA was cancelled due to failure to reach an agreement. Barr was so frustrated and his nerves so frayed by the experience that, in spring of 1932, MOMA granted him a year-long leave to get over his insomnia and his eye problems. See Michael C. Fitzgerald, Making Modernism. Picasso and the Creation of the Market for Twentieth-Century Art, University of California Press, 1995, pp. 204-213; Margaret Scolari Barr, "Our Campains", The New Criterion, special edition 1987, pp. 23-74, 28; Russell Lynes, Good Old Modern: An Intimate Portrait of the Museum of Modern Art, New York, 1973, p. 102, and Alice Goldfarb Marquis, Alfred H. 
Barr, Jr.: Missionary for the Modern, Chicago, 1989, pp. 103-105. The extent to which Barr saw Picasso as a difficult mission is evident in the fact that he called his trips to study the painter's work "campaigns," with all the connotations of peril and adventure that that word entails. Perhaps that is why he dedicated the catalogue of Picasso's first exhibition at MOMA to his wife, Margaret Scolari-Fitzmaurice, whom he call "advisor and invaluable assistant in the Picasso campaigns of 1931, 1932, 1936, 1939". See Alfred H. Barr Jr., Picasso, Fifty Years of His Art (1946) MOMA, New York, 1974.

7. Alfred Barr wanted the exhibition to represent all of Picasso's work, but he was particularly interested in including his sculptures. To that end, just weeks before the war broke out, Barr wrote to Dora Maar asking her for photographs of the artist's most recent sculptures. In a later letter, dated September 12, he spoke of the difficult circumstances: "Dear Monsieur Picasso [...] Probably our writing to you now is futile but in spite of the war -and even more because of it-we are not relaxing our efforts to make your exhibition as complete as posible. For this reason we still hope that we may be able to bring some representative pieces of your sculpture to America, as you had desired. [...] Some weeks ago, well before the outbreak of war, we asked Mlle. Maar to send photographs of the sculpture." Letter from Alfred Barr to Picasso, September 12, 1939, Paris, Musée national Picasso-Paris, don Succession Picasso, 1992.

8. Telegram from Barr to Picasso (signed Barr Modernart), December 15, [1939], 11:54 PM, Picasso 23, Rue Boetie Paris, via RADIO-FRANCE Paris, Musée national Picasso-Paris, don Succession Picasso, 1992.

9. Telegram from Barr to Picasso (signed Barr Modernart), December 15, [1939], 11:54 PM, Picasso 23, Rue Boetie Paris, via RADIO-FRANCE Paris, Musée national Picasso-Paris, don Succession Picasso, 1992.

10. Andre Géry, "But Where is Picasso?," Vogue, January 3, 1942, pp. 76, 105, and 106. It was logical to assume that, with the threat of the Nazis hovering over Paris, things would not be easy for Picasso. Neither his work nor his public persona provided any guarantee. On the contrary, German museums had taken down his paintings. An active supporter of the Republic during the Spanish Civil War, Picasso had published the satirical series The Dream and Lie of Franco, where he mocked the Fuehrer of Burgos. Now the Gestapo was rounding up Spanish Republicans in the occupied zone of France and returning them to Spain, where they were shot, hung, or tortured. Before such danger, it makes sense that Picasso would have applied for French citizenship even before the invasion of Paris on June 14. He did so on April 3, 1940, though it did not come to light until 2001 (Picasso always kept it secret). Indeed, not even Pierre Daix, the world's foremost Picasso expert and someone who was close to the artist starting in the forties, knew about it. Picasso's request for French citizenship became public knowledge when the French police's files on Picasso were returned from Moscow to Paris. The extensive voyage of those files forms part of the history of the war. Though it has yet to be proven, it appears that they were taken to Berlin after the occupation of Paris and, from there, sent to Moscow in summer of 1945, when the Third Reich fell, to be stored in the special files of the espionage services. The history, with extensive documentation, is told in Pierre Daix-Armand Israel's book Pablo Picasso. Dossiers de la prefécture de la police, 1901-1940, Paris, Éditions des Catalogues Raisonnés-Éditions Acatos, 2003.

11. This entire story, along with the photo, appears in the book written by Harriet and Sidney Janis (Picasso. The Recent Years, 1939-1946, New York, Doubleday \& Company, Inc., 1946); the edition contains reproductions of the work the artist produced during the war years, which was exhibited at Sidney Janis in New York in 1946.

12. Françoise Gillot recalled that, in those days, Picasso was as fundamental to Paris as the Eiffel Tower.

13. Letter from Alfred Barr to Picasso, September 25, 1944, Paris, Musée national Picasso-Paris, don Succession Picasso, 1992. 
14. Few of his paintings had circulated during the war years. That paucity, along with his importance as a figure and the new possibilities for exchange and circulation in the wake of the conflict, meant that the prices of his work went up at an almost unbridled pace, especially after 1950. As Françoise Gillot points out in his memoirs, though, it was harder for Daniel-Henri Kahnweiler to sell Picasso's work to North American collectors after the artist joined the Communist Party. François Gillot and Carlton Lake, Life with Picasso, New York, McGraw-Hill Book Company, 1964, p. 179.

15. "Pourquoi j'ai adhéré au parti Communiste", interview with Pol Gaillard, L'Humanité, October 29, 1944, I, p. 2, and "Why I became a Communist", New Masses, 53, No 4, October 24, 1944, p. II.

16. Ibid. See as well Gertje R. Utley, Picasso. The Communist Years, London-New Heaven, Yale University Press, 2000, p. 43.

17. According to Utley, André Fougeron was the one behind the exhibition.

18. Peter D. Whitney, "Picasso is safe: The artist was neither a traitor to his painting nor his country", San Francisco Chronicle, September 3, 1944. Whitney, a war correspondent for that newspaper, was the first North American journalist to interview Picasso after the Liberation of Paris. In 1945, Alfred Barr reprinted this text, cited by G.R. Utley, Picasso..., p. 31. Think, on the other hand, of a work like Boris Taslitzky's The Death of Danielle Casanova (1951), an enormous (150 $\mathrm{x} 180 \mathrm{~cm}$ ) painting on canvas depicting the inside of a concentration camp.

19. "Picasso et le CNE", Les Lettres francaises, October 21, 1944, p. 7, cited by G.R. Utley, Picasso...

20. A copy of the article in the New Masses is in the MOMA archives.

21. Picasso's relationship with the Communist Party always interested Barr. The MOMA archive contains a detailed report on Picasso's political activity.

22. For Barr, the difference between a Western politician and one from Nazi Germany or from Soviet Russia was crucial. Whatever the former's personal taste may be (Truman, Eisenhower, and Churchill, for instance, had all expressed their dislike for modern art), he would never attempt to impose it on his countryman or to impede the creative freedom of artists. Alfred Barr, "Is Modern Art Communistic?", The New York Times Magazine, December 14, 1952.

23. Juan Larrea, op. cit.

24. Letter from A. Barr to D. H. Kahnweiler, May 21, 1947. Alfred H. Barr, Jr. Papers, XI.B.11. The Museum of Modern Art Archives, New York

25. Letter from D. H. Kahnweiler to A. Barr, May 29, 1947. Alfred H. Barr, Jr. Papers, XI.B.11. The Museum of Modern Art Archives, New York. Translated from the French by the autor

26. Letter from D. H. Kahnweiler to A. Barr, May 29, 1947. Alfred H. Barr, Jr. Papers, XI.B.11. The Museum of Modern Art Archives, New York

27. Letter to H. D. Kahnweiler to A. Barr, May 30, 1947. Alfred H. Barr, Jr. Papers. XI.B.11. The Museum of Modern Art Archives, New York.

28. Letter to Alfred Barr to Juan Larrea, June 25, 1947, p. 2. Alfred H. Barr, Jr. Papers, XI.B.11. The Museum of Modern Art Archives, New York.

29. Translation from the letter from Juan Larrea to Alfred Barr Jr., n/d. Alfred H. Barr, Jr. Papers, XI.B.11. The Museum of Modern Art Archives, New York.

30. Translation from the letter from Juan Larrea to Alfred Barr Jr., n/d. Alfred H. Barr, Jr. Papers, XI.B.11. The Museum of Modern Art Archives, New York.

31. Translation from the letter from Juan Larrea to Alfred Barr Jr., $n / d$. Alfred H. Barr, Jr. Papers, XI.B.11. The Museum of Modern Art Archives, New York.

32. Letter from J. Larrea to P. Picasso, Mexico City, September 6, 1947. Reproduced in Juan Larrea, Guernica..., pp. 173-175.

33. Juan Larrea, Guernica..., p. 175.

34. Letter from Mr. Barr to Mr. Wheeler, October 1, 1947. Re: Guernica Symposium. Alfred H. Barr, Jr. Papers, XI.B.12. The Museum of Modern Art Archives, New York.

35. Alfred Barr, José L. Sert, Jerome Seckler, Jacques Lipchitz, Juan Larrea and Stuart Davis, Symposium on Guernica, 1947, p. 3. Print. 
36. Jerome Seckler, in Alfred Barr, José L. Sert, Jerome Seckler, Jacques Lipchitz, Juan Larrea and Stuart Davis, Symposium on Guernica, 1947, p. 15. Print.

37. Jerome Seckler, in Alfred Barr, José L. Sert, Jerome Seckler, Jacques Lipchitz, Juan Larrea and Stuart Davis, Symposium on Guernica, 1947, p. 20-21. Print.

38. Ibid., p. 26.

39. Ibid., p. 27.

40. Ibid., p. 27.

41. Ibid., p. 28

42. Ibid., p. 28.

43. Ibid., p. 28.

44. Ibid., p. 28.

45. Alfred Barr in Alfred Barr, José L. Sert, Jerome Seckler, Jacques Lipchitz, Juan Larrea and Stuart Davis, Symposium on Guernica, 1947, p. 31. Print.

46. Alfred Barr, José L. Sert, Jerome Seckler, Jacques Lipchitz, Juan Larrea and Stuart Davis, Symposium on Guernica, 1947, p. 32. Print.

47. Juan Larrea [as read by Monroe Wheeler], in Alfred Barr, José L. Sert, Jerome Seckler, Jacques Lipchitz, Juan Larrea and Stuart Davis, Symposium on Guernica, 1947, p. 40. Print.

48. Ibid., p. 45.

49. Ibid., p. 45 .

50. Ibid., p. 56.

51. Jacques Lipchitz, in Alfred Barr, José L. Sert, Jerome Seckler, Jacques Lipchitz, Juan Larrea and Stuart Davis, Symposium on Guernica, 1947, p. 57. Print.

52. Walter Pach, in Alfred Barr, José L. Sert, Jerome Seckler, Jacques Lipchitz, Juan Larrea and Stuart Davis, Symposium on Guernica, 1947, p. 79. Print.

53. Juan Ángel Muñoz, “Alemania reconoce su culpa en el bombardeo de Gernika por la Legión Cóndor hace sesenta años”, El país, Madrid, April 28, 1997. Accessed February 2, 2017. http:// elpais.com/diario/1997/04/28/espana/862178406_850215.html

\section{RÉSUMÉS}

In 1947 the publication in English of the book of Juan Larrea, Guernica. Pablo Picasso, produced a great bewilderment in Alfred Barr, who was in charge of the collections of the Museum of Modern Art, New York. The interpretation of the Spanish writer radically contradicted what Barr believed correct, based on the artist's words. In order to establish the final interpretation of the painting, Barr organized a symposium at MoMA. This essay analyzes the debate that took place through the minutes of the conference and the correspondence and interprets the reasons why it was so important to establish the meaning of the picture.

En 1947 la publicación en ingles del libro de Juan Larrea, Guernica. Pablo Picasso, New York, Curt Valentin, produjo en Alfred Barr, quien estaba a cargo de las colecciones del MoMA, un gran desconcierto. La interpretación del escritor español contradecía radicalmente la que Barr creía correcta, basada en las palabras del artista. A fin de establecer la interpretación definitiva del cuadro organiza, ese mismo año, un simposio en el MoMA. Este ensayo analiza el debate que se produjo a través de las actas de la conferencia y de la correspondencia e interpreta las razones por las cuales era tan relevante establecer el significado del cuadro. 
INDEX

Keywords : Guernica, power of images, Barr (Alfred), Picasso (Pablo), MoMA, cold war Palabras claves : Guernica, poder de las imágenes, Barr (Alfred), Picasso (Pablo), MoMA, guerra fría

\section{AUTEURS}

\section{ANDREA GIUNTA}

CONICET, University of Texas

A preliminary version of this essay was published as Andrea Giunta, "El poder de la interpretación (o cómo Alfred J. Barr explicó el

Guernica al público del MOMA)," in Andrea Giunta (Ed.), El Guernica de Picasso: El poder de la

representación. Europa, Estados Unidos y América Latina, Buenos Aires, Biblos, 2009, pp. 35-56. 